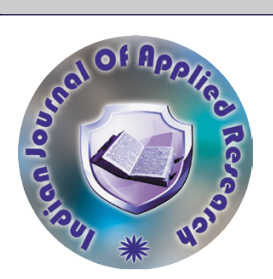

Education

\title{
STUDY OF GENDER DIFFERENCE IN CREATIVITY IN RELATION TO MATHEMATICALLY GIFTED STUDENTS OF HIGHER SECONDARY SCHOOL
}

Nirupama Pathak Asstt prof., Hitkarini Prashikshan Mahila Mahavidyalaya, Jabalpur, M.P., India Dr. Raina Tiwari* Prof., Vijayashree College Of Education, Jabalpur, M.P., India *Corresponding Author

ABSTRACT Education holds a prominent place in conditioning and shaping the personality of an individual. The purpose of education is to development of individual for solving various problem of day to day life. Descriptive survey method was used to study the creativity of the mathematically gifted students of higher secondary school. The final samples after screening on the basis of total CGPA and grade consisted of 54 mathematically gifted students and 68 mathematically non-gifted students with the help of stratified random sampling. Verbal Test of Creative Thinking by Baquer Mehdi and mathematical gifted and non-gifted criterion used to collect data. Results of the study revealed that there is no statistically significant gender difference exist between Boys and Girls in relation to giftedness in mathematics and in all the variables of verbal creativity.

KEYWORDS : Creativity, Mathematically Gifted, Gender Difference.

\section{INTRODUCTION}

Creativity is an asset of human beings. Of all the abilities that man has, which distinguish him from the rest of animal life, creativity is undoubtedly unique. Creativity is essentially human phenomena. It is a process in man, which help him to achieve

dignity and meaning in life. Creativity involves the generation of new ideas or the recombination of known, elements into something new, providing valuable solutions to a problem. It also involves motivation and emotions. A mathematically gifted students were identified by their ability of learning and understanding of mathematically ideas quickly; working systematically and accurately; high level of analytical skills; logical thinking; quick identifying ability and application of self knowledge to a new situation.

\section{RATIONALE OFTHE STUDY-}

The creative and mathematical gifted minority is one of the chief resources of development and there is need to identify, develop and encourage such talents. Mathematics subject always been important areas for students in higher secondary schools. How mathematically gifted students are related to creativity? Is there any relationship between creativity of mathematically gifted and mathematically nongifted students? The present study answering above questions.

\section{CREATIVITY AND GENDER DIFFERENCE}

Sood, S.(1999) found that only fluency-factor of creativity was found to be significantly correlated with mathematical achievement. Bharaj,M.(2013), found in his study that gifted girls and gifted boys shows no differences in their creative thinking. But, as compared to other students gifted boys and girls have shown greater creativity. No significant difference exist between creativity of boys and girls (Bharaj,M,2013; Lugade,2015; Sedighe, S \& Hossein, J, 2015; Godara,S,2015). On the other hands some researchers believed that gender plays an important role in creativity. Girls are more creative than boys (Kettler, Todd,2017; Dalal,S \& Rani,G,2013; Lee Kang Sup et al,2005), Boys are more creative than boys (Mary,2004). Creativity and giftedness are related with each other (Franzis, et al,2006; Dalal, S, \& Rani, G, 2013).

\section{OBJECTIVES OF THE STUDY}

To study gender difference in creativity- (Fluency, flexibility and originality) of mathematically gifted students of higher secondary schools.

\section{HYPOTHESES OF THE STUDY}

There is no significant gender difference in Creativity- (Fluency, Flexibility and Originality) of mathematically gifted Boys/ Girls/ (Boys+ Girls) students of higher secondary schools;

\section{RESEARCH METHODOLOGY:}

Descriptive survey method was used to study the creativity of the mathematically gifted students of higher secondary school. The subjects were selected with the help of stratified random sampling technique. The difference between boys and girls with regard to their

\section{Creativity studied.}

\section{SAMPLE:}

600 students of class XI studying in government and private higher secondary schools of Jabalpur were selected randomly. Out of them 300 were boys and 300 were girls. The final samples after screening on the basis of total CGPA and grade consisted of 54 mathematically gifted students and 68 mathematically non-gifted students.

\section{TOOLS:}

Following tools were used to collect data:

1. Mathematically Gifted-Criteria of more than 9.5 CGPA + 'A' grade in mathematics in class X Board examination.

2. Mathematically Non-Gifted-Criteria of less than 7.5 CGPA + ' $\mathrm{C}$ ' grade in mathematics in class X Board examination.

3. Verbal Test of Creative Thinking by Baquer Mehdi

\section{STATISTICALANALYSIS:}

Mean, Standard Deviation t-test/ Critical Ratio was computed to analyse the data and testing the hypotheses.

RESULTS AND DISCUSSION:

Table No. 01: Comparative results of gender difference in Fluencyfactor of creativity in relation to mathematically gifted students

\begin{tabular}{|l|l|l|l|l|l|l|}
\hline Nature & Gender & $\mathbf{N}$ & $\mathbf{M}$ & S.D. & t/C.R. & 'P' Value \\
\hline Mathematically Gifted & Boys & 20 & 38.01 & 7.32 & 0.86 & $>0.05$ \\
\cline { 2 - 6 } & Girls & 34 & 36.09 & 8.28 & & \\
\hline $\begin{array}{l}\text { Mathematically Non- } \\
\text { Gifted }\end{array}$ & Boys & 18 & 21.52 & 8.54 & 0.46 & $>0.05$ \\
\cline { 2 - 5 } & Girls & 50 & 20.50 & 7.82 & & \\
\hline
\end{tabular}

Degree of freedom $-52,66$ Value for significance at 0.05 level -2.00 , 1.99

Value for significance at 0.01 level-2.66, 2.64

As shown in the above table the results of gender difference in the Fluency- factor of creativity of both mathematically gifted and nongifted students, show that there is no statistically significant gender difference between Boys and Girls, the obtained values of $\mathrm{t} / \mathrm{C}$.R. are 0.86 and 0.46 respectively, which are not significant at 0.05 levels of significance.

Thus, from the above results it may be concluded that there is no statistically significant gender difference in the Fluency- factor of creativity of both mathematically gifted and non-gifted students.

Table No. 02: Comparative results of gender difference in Flexibility-factor of creativity in relation to mathematically gifted students:

\begin{tabular}{|l|l|l|l|l|l|l|}
\hline Nature & Gender & N & M & S.D. & t/C.R. & 'P' Value \\
\hline $\begin{array}{l}\text { Mathematically } \\
\text { Gifted }\end{array}$ & Boys & 20 & 27.83 & 5.64 & 0.89 & $>0.05$ \\
\cline { 2 - 5 } & Girls & 34 & 26.53 & 4.93 & & \\
\hline
\end{tabular}


Mathematically Non-Gifted

Girls

\begin{tabular}{|l|l|l|l|}
18 & 15.24 & 4.93 & 0.17
\end{tabular}

$>0.05$

Degree of freedom - 52, 66 Value for significance at 0.05 level - 2.00, 1.9

As shown in the above table, comparative results of gender difference in the Flexibility-factor of creativity of both groups mathematically gifted and non-gifted shows there is no statistically significant gender difference between Boys and Girls. The obtained values of t/C.R. are 0.89 and 0.17 respectively, which are not significant at 0.05 levels of significance.

Thus, from the above results it may be inferred that there is no statistically significant gender difference in the Flexibility-factor of creativity of both mathematically gifted and non-gifted students. Mathematically gifted and non-gifted Boys and Girls do not differ in Flexibility-factor of creativity

Table No. 03 Comparative results of gender difference in Originality-factor of creativity in relation to mathematically gifted students

\begin{tabular}{|l|l|l|l|l|l|l|}
\hline Nature & Gender & $\mathbf{N}$ & $\mathbf{M}$ & S.D. & t/C.R. & 'P' Value \\
\cline { 1 - 7 } $\begin{array}{l}\text { Mathematically } \\
\text { Gifted }\end{array}$ & Boys & 20 & 26.16 & 11.89 & 0.21 & $>0.05$ \\
\cline { 2 - 7 } & Girls & 34 & 26.82 & 10.54 & & \\
\hline \multirow{2}{*}{$\begin{array}{l}\text { Mathematically } \\
\text { Non-Gifted }\end{array}$} & Boys & 18 & 9.01 & 5.57 & 0.79 & $>0.05$ \\
\cline { 2 - 5 } & Girls & 50 & 9.86 & 3.13 & & \\
\hline
\end{tabular}

Degree of freedom - 52, 66 Value for significance at 0.05 level -2.00 , 1.99

As shown in the above table, comparative results of gender difference in the Originality - factor of creativity of both groups namely, mathematically gifted and non-gifted students show that there is no statistically significant gender difference between Boys and Girls. The obtained values of t/C.R. are 0.21 and 0.79 respectively, which are not significant at 0.05 levels of significance.

Thus, from the above results it may be inferred that there is no statistically significant gender difference in the originality-factor of creativity of both mathematically gifted and non-gifted students. Mathematically gifted and non-gifted Boys and Girls do not differ in Originality-factor of creativity.

Thus, there was no significant gender difference observed in Fluency, Flexibility and Originality- factor of Creativity. This can be attributed to both boys and girls possess equal motivation and interest to express creative potentials. And also because of similar treatment in their upbringing, recreational facilities and educational facilities provided to both mathematically gifted and mathematically non-gifted boys and girls in home and at school. The results of the finding are supported by Sedighe et al, (2015) who found that no significant gender difference between gifted boys and gifted girls with regard to their creativity.

Thus, on the basis of above results the above hypothesis not accepted.

\section{CONCLUSIONS:}

There is no statistically significant gender difference exist in relation to giftedness in mathematics and Fluency-factor of creativity. The calculated values of t/C.R. (0.86 and 0.46$)$ are significantly lower than the table values of t/C.R. (2.00 and 1.99) respectively at 0.05 level of significance. Mathematically gifted and mathematically non-gifted Boys and Girls do not differ significantly in Fluency-factor of creativity. (Reference table no. 01)

There is no statistically significant gender difference exist between Boys and Girls in relation to giftedness in mathematics and Flexibilityfactor of creativity. The calculated values of t/C.R. (0.89 and 0.17) are significantly lower than the table values of t/C.R. (2.00 and 1.99) respectively at 0.05 level of significance. Mathematically gifted and mathematically non-gifted Boys and Girls do not differ significantly in Flexibility-factor of creativity. (Reference table no. 02).

There is no statistically significant gender difference exist between Boys and Girls in relation to giftedness in mathematics and Originality-factor of creativity. The calculated values of t/C.R. (0.21 and 0.79 ) are significantly lower than the table values of t/C.R. (2.00 and 1.99) respectively at 0.05 level of significance. Mathematically gifted and mathematically non-gifted Boys and Girls do not differ significantly in Originality-factor of creativity. (Reference table no. 03).

\section{REFERENCES:}

1. Kettler, T. (2014). Critical Thinking Skills Among Elementary School Students: Comparing Identified Gifted and General Education Student Performance. Gifted Child Quarterly;58(2):127-36.

2. Franzis, H.H., Holling,H.W. (2006). Relationship of -intelligence and creativity in gifted and non-gifted students: An investigation of threshold theory. Personality and Individual Differences; 1(31):159-70.

3. Bharaj, M (2013). Multi-dimensional study of the intellectual gifted adolescents. MIER Journal of Educational Studies, Trends \& Practices; 3(1):1-15.

4. Dalal S, Rani G (2013). Relationship of creativity and intelligence of senior secondary students. International Journal of Humanities and Social Science Invention; 7: 70-74.

5. Lugade S.P. \& Kadam P.B. (2015). A Correlation of creativity, intelligence and academic achievement of 9 std. Students. Indian Streams Research Journal; 5(9). ISSN 22307850

6. Godara, S, (2015). A study of creativity of senior secondary students in relation to their intelligence and gender. International Journal of Education, Vol. 4(1), March. 2015. ISSN 2319-2323.

7. Sedighe, S., Jenaabadi, H. (2015). Comparison of creativity and self-confidence of gifted and normal high school students of district two in Zahendan. Psychology. 2015;6:1750-1755. 